\title{
Production of clean water in agriculture headwater catchments: A model based on the payment for environmental services
}

\author{
Teresa Cristina Tarlé Pissarra ${ }^{\mathrm{a}, \mathrm{d}}$, Luís Filipe Sanches Fernandes ${ }^{\mathrm{b}, \mathrm{d}}$, Fernando António Leal Pacheco ${ }^{\mathrm{c}, \mathrm{d}, *}$ \\ a Faculdade de Ciências Agrárias e Veterinárias, Universidade Estadual Paulista (UNESP), Via de Acesso Prof. Paulo Donato Castellane, s/n, Jaboticabal, SP 14884-900, Brazil \\ b CITAB - Centro de Investigação e Tecnologias Agroambientais e Biológicas, Universidade de Trás-os-Montes e Alto Douro, Ap. 1013, 5001-801 Vila Real, Portugal \\ c CQVR - Centro de Química de Vila Real, Universidade de Trás-os-Montes e Alto Douro, Ap. 1013, 5001-801 Vila Real, Portugal \\ d POLUS - Grupo de Política de Uso do Solo, Universidade Estadual Paulista (UNESP), Via de Acesso Prof. Paulo Donato Castellane, s/n, Jaboticabal, SP 14884-900, Brazil
}

\section{H I G H L I G H T S}

- Agriculture can coexist with clean water production in headwater catchments.

- Coexistence implies conversion from intensive crop production to agro-forestry

- The payment for ecosystem services (PES) model (ACWY) predicts coexistence costs

- The payment returns to farmers as function of water production and conversion costs

- Monitoring, time limit, political will and funds are keys for ACWY and PES success

\section{A R T I C L E I N F O}

\section{Article history:}

Received 26 February 2021

Received in revised form 20 April 2021

Accepted 20 April 2021

Available online 26 April 2021

Editor: Damia Barcelo

\section{Keywords:}

Headwater catchments

Water provision services

Land conversion

Agro-forestry sustainable production

Best management practices

Payment for ecosystem services

\section{G R A P H I C A L A B S T R A C T}

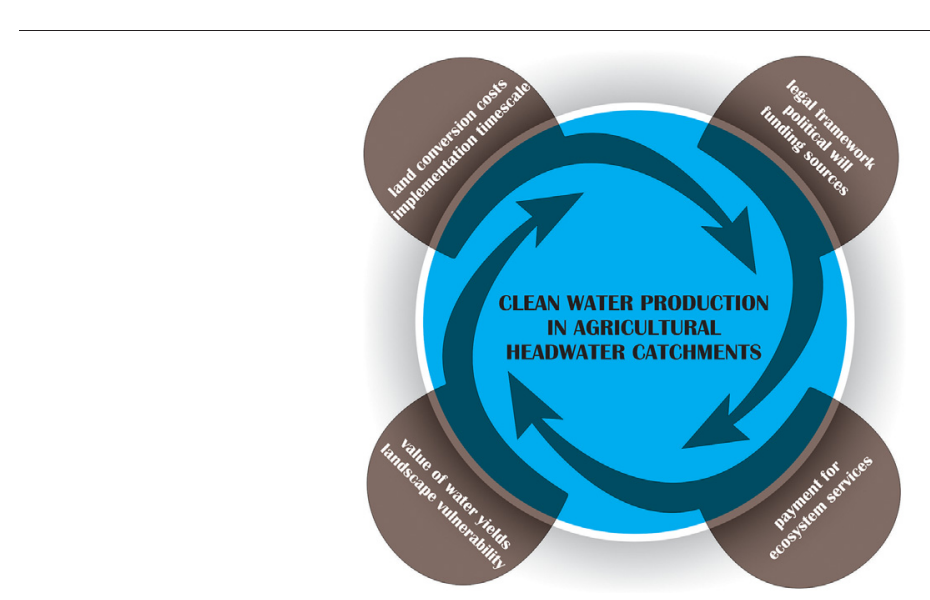

\begin{abstract}
A B S T R A C T
This study aimed to present a payment for ecosystem services model that promotes a symbiotic coexistence between agriculture and clean water production. The model favors application to headwater catchments where clean water production is expected. However, the frequent invasion of these areas with intensive agriculture and livestock production systems affects water quality threatening the use of this resource, namely as drinking water. The proposed Agriculture for Clean Water Yield (ACWY) model reconciles agriculture with clean water production through the incentive approach, giving the farmers a financial compensation if they are willing to replace intensive by sustainable agriculture and livestock production systems, namely agro-forestry systems. The reconciliation through the incentive approach is justified because clean water and food are both vital goods for human survival. The compensation rises as function of increasing catchment water yield capacity and conversion costs. For example, landowners receive more if land conversion occurs in slopping than undulated landscapes. The model applied to Fazenda Glória watershed, composed of 19 headwater catchments (96.7 ha on average), proposed financial incentives in the range 218.73-576.5 US\$/ha/year depending on the catchment's water yield capacity, which rise to 284.35-749.45 US\$/ha/year if conversions occur in extreme vulnerable areas. The watershed, located in São Paulo state, Brazil, covers $18.4 \mathrm{~km}^{2}$ and is the source of drinking water to 70,000 people living in Jaboticabal city. Monitoring is essential to assess the performance of ACWY and adjust the compensation dynamically. For instance, noteworthy improvements in water yields and water quality or land conversions
\end{abstract}

\footnotetext{
* Corresponding author at: CQVR - Centro de Química de Vila Real, Universidade de Trás-os-Montes e Alto Douro, Ap. 1013, 5001-801 Vila Real, Portugal.

E-mail addresses: teresa.pissarra@unesp.br (T.C.T. Pissarra), lfilipe@utad.pt (L.F. Sanches Fernandes), fpacheco@utad.pt (F.A.L. Pacheco).
} 
performed in short periods can expect the most generous compensation. Two concerns about implementing the model in Fazenda Glória rely on the lack of political will in spite of existing federal and state legal support, as well as on the financial sources to make the model a real project.

\section{Introduction}

The Millennium Ecosystem Assessment (MEA, 2005) presented conceptual and methodological approaches capable to enhance the contribution of ecosystems to human welfare. There are many benefits people can obtain from ecosystems (Canova et al., 2019; Ola et al., 2019; Westerink et al., 2017), such as goods and services (Sagoff, 2011; Thomson et al., 2014). However, to keep them in the long-term humanity must change consumption and production towards more sustainable patterns (Lampert and Hastings, 2019).

The ecosystem services rendered by agriculture include the regulation of soil and water quality, carbon sequestration, support for biodiversity and cultural services (Power, 2010). The works of BellverDomingo et al. (2016) as well as of Tsur (2020) highlighted the social dimension of water services in general, namely as regards quality and supply. However, agriculture development without adaptation normally causes water quality degradation and affects supply (Pacheco et al., 2018). Thus, reconsidering the sustainability of food production through engaging farmers into water resources protection should be central to land-use policies.

One path towards the coupling of food and clean water production is through the economic valuation of water in headwater catchments used for agriculture and livestock pasturing. These catchments are particularly important for clean water production given their upstream location in the river basin, but can be affected if agriculture and livestock pasturing develop without proper attention over the water resources. Various authors set up nexus between human activities and the economic value of ecosystem services at the catchment scale, including water services. The studies proposed trade-offs between the provision of services and the impacts of anthropic activities, where providers receive compensation from whom causes the impact. The studied activities included deforestation (Andrade et al., 2020; Araújo and Chrispim, 2017), coal mining, water uses and the need to maintain ecological river flows (Cheng et al., 2019), cropland declines (Canova et al., 2019), reallocation or diversion of water (Liu et al., 2018; Settre et al., 2019; Yu and $\mathrm{Lu}, 2018$ ), among others. Some research went beyond the institution of nexus and designed compensation schemes valuable for policymaking and the pursuit of social equity. The most frequent scheme relies on the payment for ecosystem services (PES) concept (Fan and Chen, 2019; Fu et al., 2018; Geussens et al., 2019; Sedghamiz et al., 2018; Sheng and Webber, 2017).

The PES can also be the route to incentive the production of clean water in headwater catchments. Agriculture (de Moraes et al., 2017) and livestock pasturing (Oliveira et al., 2019) are human activities that impact water in these upland areas but are also providers of ecosystem goods relevant for the society, namely food (Begossi et al., 2011; Ghaley et al., 2014). Besides, the studies of Alcon et al. (2020), Alves-Pinto et al. (2017) and de Sartre et al. (2016) recognized a conflict between agricultural expansion and the natural ecosystem, but also recalled the variety of ecosystem benefits granted by a sustainably managed intercropped forest, agriculture and cattle-ranching production system. Therefore, the use of headwater catchments for food production could be reconciled with the production of clean water if a PES model acknowledged agriculture and livestock pasturing as providers of essential goods and recognized the environmental benefit of implementing these activities sustainably. In practice, the model could estimate the cost of changing intensive to agro-forestry production systems concomitantly with the implementation of best management practices, integrating the result in the PES value. This value would compensate farmers willing to change their production systems to the more sustainable ones, allowing the symbiotic coexistence of an essential economic activity and a healthy environment (Parkhurst, 2013; Ruffo and Kareiva, 2009).

There is plentiful literature on the nexus food production versus preservation of water resources in agricultural areas (Burkhard et al., 2012; Koschke et al., 2012; Maes et al., 2016). The contribution of environmental factors to that connection, such as land vulnerability (Santos et al., 2016) or land use conflicts (Valle Junior et al., 2014a, 2014b; Valle Junior et al., 2015; Costa et al., 2019), have also concerned various authors. However, the existing approaches to the PES commonly fail to integrate the full inventory of conversion costs and implementation of best management practices in the evaluation framework, and barely rank conversion costs according to land vulnerability (e.g., conversions are more expensive in steep slopes than in plains). They also frequently fail to index the PES value to the amount of water produced in the catchment. The shortcomings of existing methods were the motivation to develop this research and represent the novelty of our study. Thus, in order to contribute with a framework capable to assess the PES as function of headwater yield capacity and landscape vulnerability, the purpose of this study was to present the Agricultural for Clean Water Yield (ACWY) model. In the ACWY model, the reference value for the PES compensation is the net income per hectare that farmers will lose while implementing the land conversions, because forest replaces some cropland area reducing crop yields. This net income depends on the crop. Then, the PES value rises for larger headwater yields as well as for larger conversion costs not ruling out those related with the catchment's environmental vulnerability. The ACWY model calculates the PES in the form of a financial incentive to landowners that ensures a better water quality if a correct production system conversion occurs.

\section{Materials and methods}

\subsection{Study area}

The study area comprises headwater catchments of Fazenda Glória stream watershed (area: $18.4 \mathrm{~km}^{2}$ ), located in the municipal district of Taquaritinga, State of São Paulo, Brazil (Fig. 1). The reference geographic coordinates for the area are Latitude $-21^{\circ} 21^{\prime} \mathrm{S}$ and Longitude $48^{\circ} 31^{\prime} \mathrm{W}$. The stream is a tributary of Córrego Rico River, which in turn discharges into Mogi-Guaçú River. The water produced in the headwater area supplies more than 70,000 people living in the Jaboticabal city. The Mogi-Guaçu Hydrographic Basin Committee (CBH-MOGI) Water Resources Management Unit no. 09 regulates the supply system in Jaboticabal and other 42 municipalities with a total urban area around $15,000 \mathrm{~m}^{2}$ and a local population of $1,466,062$ inhabitants (IBGE, 2010). The prominent economic activity sectors in the region are the agribusiness, vegetable oils and beverages, refrigerators, and the paper and cellulose industries. Six hydro-mineral resorts are references for the tourism sector. The region comprises $10.5 \%$ of vegetation cover (SIGRH, 2020). The water demand increased over the last years due to population and per capita use increases, while periods of drought became more frequent. These water security issues concern the political agents because water supply and demand are in a tenuous balance already.

The climate around Fazenda Glória is tropical with annual rainfall around $1200 \mathrm{~mm}$ and temperatures ranging from $22{ }^{\circ} \mathrm{C}$ in summer and $18{ }^{\circ} \mathrm{C}$ in winter. The altitude varies between 578 and 722 m.a.s.l. 


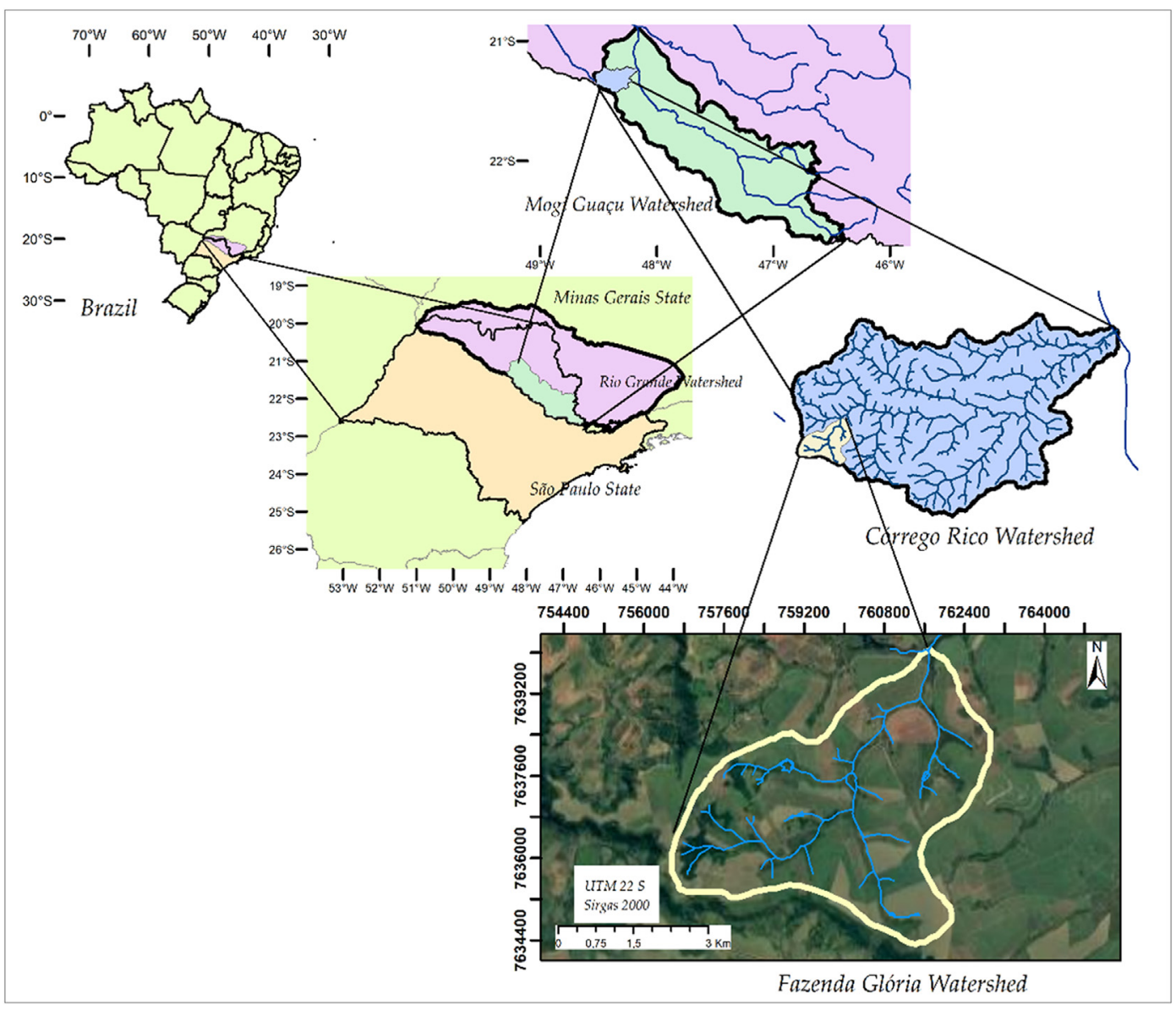

Fig. 1. Study area: Fazenda Glória stream headwater basin, located in Taquaritinga municipality, state of São Paulo, Brazil.

Geology comprises Cretaceous formations, namely sandstone outcrops from Vale do Rio Peixe and Marília formations (Bauru Group), which overlay basaltic lava flows and associated dolerite dykes from the Serra Geral formation (Fernandes and Coimbra, 1996, 2000; Rodrigues et al., 2013). From a hydrogeologic point of view, the sedimentary sequence integrates the Marília aquifer while the basaltic rocks integrate the Serra Geral aquifer. The Marília aquifer is porous, unconfined to semi-confined, not continuous, heterogeneous and anisotropic, with a thickness around $180 \mathrm{~m}$. The Serra Geral aquifer is also unconfined to semi-confined, not continuous, heterogeneous and anisotropic, but is fractured with a thickness around $150 \mathrm{~m}$ and transmissivity in the range $1-700 \mathrm{~m}^{2} / \mathrm{h}$, allowing abstractions from individual wells in the interval $5-70 \mathrm{~m}^{3} / \mathrm{h}$ (Hirata et al., 2007). The major soil types are redyellow argisols, oxisols, and yellow latosol (Camargo et al., 1987; Oliveira, 1999). The land uses changed from tropical native tree vegetation to agriculture over the last 150 years, related to Italian, Japanese and Spanish settlements. Initially, the land use conversions replaced the native vegetation by coffee plantations. Then the citrus plantations came and nowadays the sugar cane fields dominate the landscape. Soil management in the sugar cane and livestock pasturing areas brought consequences for water resources. The depth of groundwater has visibly increased reducing the water resource while the quality of water has declined (Lopes et al., 2010; Saran et al., 2018). The anthropic influence over some water quality parameters is evident. A study by Donadio et al. (2005) reported average turbidity in spring waters from Córrego Rico located near agriculture areas close to 16.3 NTU and near vegetated areas close to $6.6 \mathrm{NTU}$. In that study, the effect of season affected the average phosphorus concentrations, which were around $1.9 \mathrm{mg} / \mathrm{L}$ in the rainy season and around $0.7 \mathrm{mg} / \mathrm{L}$ in the dry season. Herbicides appeared in tens of springs and wells located in a rural area of Jaboticabal city, namely hexazinone, imazapyrand, sulfentrazone and (mostly) clomazone (Santos et al., 2016). In rural properties of Córrego Rico basin, the lack of animal and human waste treatment, as well as the lack of spring and well water treatment, represented risks to consumer health due to inadequate microbiological quality and the presence of $\mathrm{Fe}$, $\mathrm{Mn}, \mathrm{Cd}, \mathrm{Cr}$ and $\mathrm{Pb}$ above the maximum limit allowed for human consumption (Pinto, 2011). The water of Córrego Rico stream was inadequate for public supply, considering the fecal contamination by total coliforms, Escherichia coli and sulfite reducing Clostridia, especially during the rainy season and in domestic containers (Scholten et al., 2012; Silva et al., 2016).

\subsection{A framework model for clean water production in headwater catchments}

The Agriculture for Clean Water Yield (ACWY) model conceives the watershed as the space where human activities and clean water production can be reconciled. Further, it considers headwater catchments as portions of a watershed where the production of clean water is more likely because of their position in more pristine regions, irrespective of their frequent occupation with agriculture activities such as crop or livestock production. The workflow to implement the ACWY model comprehends four main steps (Fig. 2). Firstly, the headwater catchments are valued according to their water yields because the focus of ACWY is water production. Secondly, agro-forestry systems replace monocultures concomitantly with the implementation of best management practices (sustainable agriculture), to ensure production of quality water. Thirdly, a geographic information system analyzes the watershed 

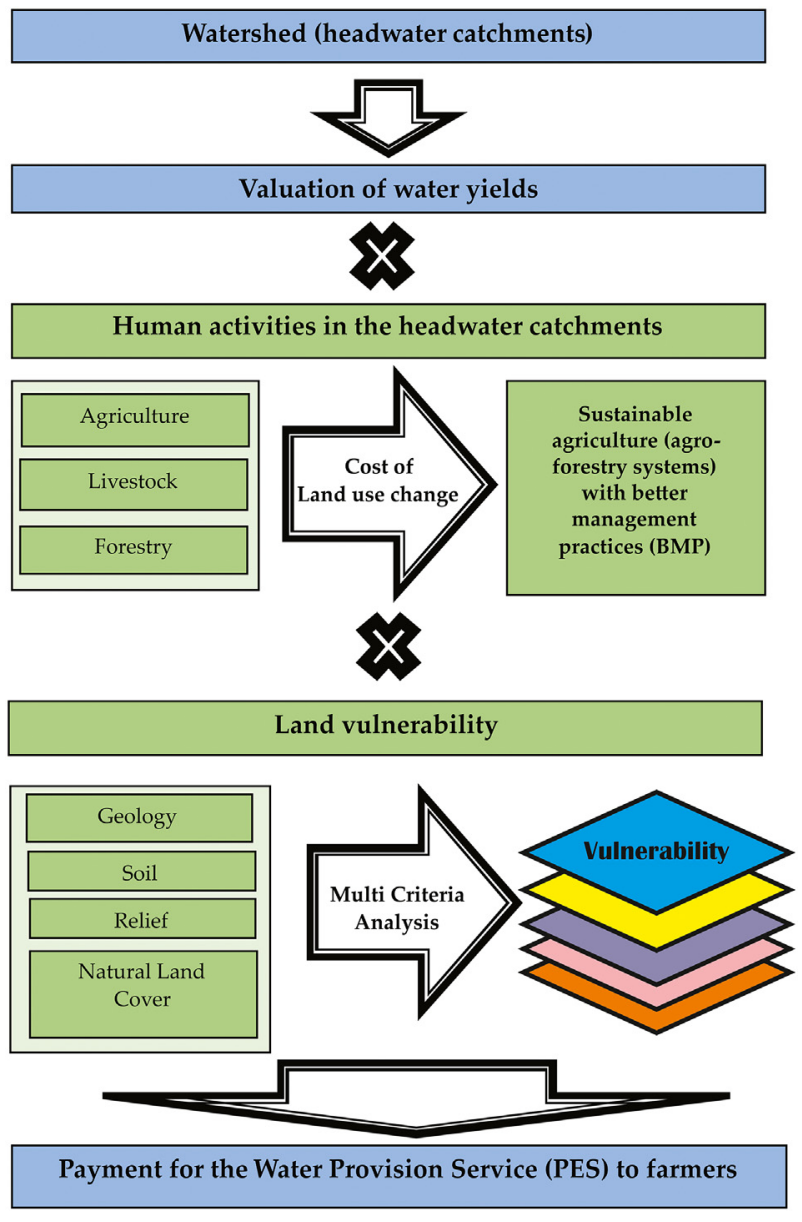

Fig. 2. Workflow to implement the Agricultural for Clean Water Yield model.

from a biophysical vulnerability standpoint, because land use conversions and the implementation of best management practices must adapt to lithologic and soil types as well as relief and land cover characteristics to be efficient. In the context of ACWY, sustainable agriculture and best management practices represent a provisioning service (clean water) from which a financial return to the farmers is expected, received from the beneficiaries (e.g., users or consumers). Thus, the fourth step estimates the financial return (PES - payment for the water service) through integration of land-use conversion costs, including the role of vulnerability, and the valuation of water yields.

The replacement of extensive monocultures by agro-forestry systems, concomitantly with the implementation of best management practices (BMPs) such as managed nutrient applications, scheduled irrigation, vegetation buffers, terracing, land leveling, among others, ensure improved water quality discharged from the headwater catchments (Duffy et al., 2020; Ferreira et al., 2019; Wang et al., 2020). However, these land use conversions and BMPs are costly the reason why landowners usually renounce to apply them, unless they are driven by some incentive, financial or other (Haile et al., 2019; Jones et al., 2020), as proposed in the ACWY. In general, the incentive should be proportional to production losses caused by land use conversions that reduce the cropland areas and hence crop yields, but other factors play a role in the equation. For instance, it is reasonable that conversions made in large-yield catchments are valued more relative to those implemented in small-yield catchments, given the aforementioned focus on water production. Land vulnerability is also a factor because conversions and implementation of BMPs are more challenging in high vulnerability areas (e.g., with steeper slopes) than in low vulnerability areas (e.g., plains). In this case, a spatial multi criteria analysis based on selected environmental attributes will define vulnerability across the watershed that will assist the evaluation of PES. Overall, the rationale behind the ACWY model is that farmers working in headwater catchments produce an ecosystem good essential to life (food) and therefore merit the benefit of a PES. However, the benefit is justified as much as they do protect the quality of significant water yields, considering the costs of necessary land use conversions and implementation of best management practices, namely as regards land vulnerability and reduction of cropland area.

\subsubsection{Model details}

The storage of water in a watershed, in either the surface or underground is paramount to water supply. Conserving the functions of a watershed (e.g., recharge, depuration) to allow the provision of clean water as service is a humankind obligation. As recognized by numerous authors, the headwater areas influence water quality and flow conditions, and contribute to larger downstream water bodies (Andrade et al., 2020; Bai et al., 2011; Cheng et al., 2019).

When the headwater catchments are capable to provide water to the society, a return from society is expected. The association of food producers to environmental protection issues is necessary in that regard (Wang et al., 2018, 2019). The land uses on headwaters can cause strong pressure on water storage and quality, given the frequent occupation of these areas by intensive agriculture, livestock or forestry production that consume and can contaminate the resource. The producers should therefore consider the preservation or restoration of water resources to keep their role as environmental service. The shifting from intensive agricultural land use to agroforestry organic farming using best management practices, as well as the commitment to preserve that agro-ecosystem in the headwaters, is the collective initiative expected from farmers to keep producing clean water in the long-term.

The ACWY model uses the incentive approach to persuade farmers working on the headwater catchments to modify their management. This is one among the strategies tempted to restore degraded environments, which also include caps and charges (Parrado et al., 2020). The incentive is a return value to compensate producers from economic losses related to land use conversions and implementation of best management practices. Evaluating these losses is therefore the key to set on the incentive. The ACWY model indexes the incentive to the net income resulting from crop production, because income is a fundamental reference to promote the desired land use changes (Gutzler et al., 2015). The net incomes vary across the planet and depend on the crop. The ACWY model considers $50 \%$ of that income (trade-off coefficient) enough to compensate producers for the implementation of agro-ecosystems. This is similar to say that crop production costs in the agro-ecosystem are generally 1.5 fold the costs of intensive production. In the former case, however, there will be the benefit to preserve water cleaner for the targeted supply system. On the other hand, the system users should pay to sustain the service.

The ACWY model carefully analyses the headwater catchments before operating the required land use changes, because conversion costs depend on land vulnerability set by topographic, pedological, geologic and land cover parameters. Land vulnerability measures the longterm capacity of catchments to control natural erosion and buffer water-quality degradation. In the vulnerable areas, soil losses and water quality are particularly sensitive to land use changes (Valle Junior et al., 2014a, 2014b; Pacheco et al., 2014; Pacheco and Sanches Fernandes, 2016), which is why land conversions come with erosion control measures raising their cost. To compensate producers in this case, the service will be more expensive in vulnerable areas. In turn, producers must develop sustainable crop production based on longterm planning goals, which include the maintenance of permanently preserved areas legally protected by Brazilian environmental laws (Brasil, 2012). The ACWY model assessed land vulnerability using the method of Crepani (in Ribeiro and Campos, 2007). 
The benefits of implementing the ACWY model and concomitantly the PES are productive farmlands in a healthy environment (Alavalapati and Mercer, 2004). However, the success of any PES scheme relies on land use policies and funds derived therefrom to provide the necessary economic incentives. In the present case where the service is clean water production, the funding for the PES may come from the government, international agencies, local communities, water companies, hydropower producers, flood protection organizations, or private companies. In the end, the cost will probably pass to final users or consumers.

\subsubsection{The mathematical handling of ACWY}

The water yielding from a hydrographic basin $\left(W_{\mathrm{y}}\right.$; $\left.\left[\mathrm{LT}^{-1}\right]\right)$ is the ratio of an instream flow measured at the basin's outlet $\left(I_{f} ;\left[\mathrm{L}^{3} \mathrm{~T}^{-1}\right]\right)$ and the basin's surface area $\left(S_{b a} ;\left[\mathrm{L}^{2}\right]\right)$ :

$W_{y}=\left(\frac{I_{f}}{S_{b a}}\right)$

The service provided by water yielding from a sub-basin (ES_ $W_{y}$; $[-])$ is the proportion of $W_{\mathrm{y}}$ relative to $\overline{W_{y}}$, which is the average water yielding from the full inventory of sub-basins within the basin:

$E S_{-} W_{y}=\frac{W_{y}}{W_{y}}$

A corollary of Eq. (2) is that ES_ $W_{\mathrm{y}}=1$ for an entire headwater basin. Besides, the service of sub-basins producing more water than the average yield is ES_ $W_{\mathrm{y}}>1$ whereas for the less productive subbasins the service is ES_ $W_{\mathrm{y}}<1$. Using the GIS software (e.g., ArcMap, version 10.5.1; https://desktop.arcgis.com), the ES_W $W_{\mathrm{y}}$ values are allocated to the sub-basins (catchments). A polygon shapefile describes the boundaries of basin and sub-basins as well as the corresponding attribute table. Subsequently, a conversion tool uses the shapefile and its ES_ $W_{\mathrm{y}}$ attribute to produce a raster map of ES_W $W_{\mathrm{y}}$ scores.

The service is valued according to the ES_ $W_{\mathrm{y}}$ but also accounts for the land conversion costs and vulnerability. The net income resulting from crop production $\left(P_{\mathrm{cp}}\right.$; $\left[\right.$ US $\left.\left.\$ . \mathrm{L}^{-2} \mathrm{~T}^{-1}\right]\right)$ in the catchment multiplied by the trade-off coefficient (Factor $X ;[-]$ ) measures the impact of land conversion on the service value. In the present study, the most represented crop defines a $P_{\mathrm{cp}}$ for the entire watershed, while Factor $X=$ 0.5 . The assumptions about Factor $X$ and $P_{\mathrm{cp}}$ can, however, change from place to place, region to region or even country to country, or as function of available crop distribution within the studied area.

A conventional multi criteria analysis implemented in the GIS software evaluates the influence of land vulnerability $\left(V_{u} ;[-]\right)$ on the PES value, where $V_{\mathrm{u}}$ derives from the spatial distribution of four parameters $\left(Y_{\mathrm{i}} ;[-]\right)$ : lithology, soil type, slope gradient and land cover class:

$V_{u}(j)=\sum_{i=1}^{n} w_{i} Y_{i}(j)$

where $Y_{\mathrm{i}}(\mathrm{j})$ is the rating of parameter $i$ at location $j$. The larger ratings indicate the more vulnerable classes. For example, the rating of lithology will be 5 if location $j$ falls on the Vale do Rio Peixe formation and 7 if it falls on the Marilia formation. Similarly, the rating of slope gradient will be 3 for points located in undulating landscapes and 9 for points located in steep hillslopes (please see Table 1 below). The value of $w_{\mathrm{i}}$ (weight; $[-]$ ) is the regional importance of $Y_{\mathrm{i}}$ (at the basin scale) for the evaluation of $V_{\mathrm{u}}$. The larger weights point to the more important parameters. Finally, $n$ is the number of parameters $(n=4)$ used to evaluate the $V_{\mathrm{u}}$. Raster maps describe the spatial distribution of parameters. On a pixel-by-pixel basis, where each pixel represents a location in the headwater basin, GIS functions reclassify the parameters into their ratings and multiply them by the corresponding weights to obtain the final $V_{\mathrm{u}}$
Table 1

Ratings of environmental attribute classes, ranking of environmental attributes and optimized ranks (weights) determined by the Analytical Hierarchy Process (Saaty, 1977). The slope classes are in keeping with the Unites States Department of Agriculture Natural Resources Conservation Service.

\begin{tabular}{llll}
\hline Environmental attribute and related classes & Rating & Rank & Weight \\
\hline Geology & 5 & 1 & 0.056 \\
$\quad$ Vale do Rio do Peixe formation & 7 & & \\
$\quad$ Marília formation & & 3 & 0.122 \\
Soil & 5 & & \\
$\quad$ Latosol & 7 & & 0.263 \\
Argisol & & 5 & \\
Slope Class (\%) / Relief & 1 & & \\
0-3 Nearly level & 3 & & \\
3-8 Undulating & 5 & & \\
8-15 Rolling & 7 & & \\
15-20 Hilly & 9 & & \\
$\quad>20$ Steep & & 7 & \\
Land Use and Land Cover & 7 & & \\
Forest & 5 & & \\
Pasture & 3 & & \\
Agriculture & & & \\
\hline
\end{tabular}

map. Considering the range of $V_{\mathrm{u}}$ values, four equal-interval (range/4) vulnerability classes are set to: Class (1) low vulnerability; class (2) vulnerable; class (3) high vulnerability; class (4) extreme vulnerability. Vulnerability represents an impact (increase) on the conversion costs of production systems. In the present study, this impact was set to 1 (no impact) for class (1), $10 \%$ increase for class (2), $20 \%$ increase for class (3) and 30\% increase for class (4). Besides, these vulnerability impact factors represented $V_{\mathrm{u}}$ in Eq. (4). Therefore, the PES value or Agricultural for Clean Water Yield rate (ACWYr; [US\$. $\left.\left.\mathrm{L}^{-2} \mathrm{~T}^{-1}\right]\right)$ is:

$A C W Y_{r}=E S \_W_{y} \times(P c p \times$ Factor $X) \times V_{u}$

\subsection{Dataset development}

\subsubsection{Watershed and catchments}

The delineation of Fazenda Glória stream watershed (the studied headwater basin), of tributary catchments and corresponding drainage networks has resorted to the "Delineate Watershed" function of Soil and Water Assessment Tool (ArcSWAT; https://swat.tamu.edu/software/ arcswat). The digital elevation model (DEM) was the input data for the delineation function. The DEM was a raster image composed of $12.5 \times 12.5 \mathrm{~m}$ grid cells. The USGS personnel downloaded the raster following a user registration at the Advanced Land Observing Satellite (ALOS) PALSAR searchable data archive maintained at the United States Geological Survey (USGS) Earth Resources Observation Science (EROS) Center (uso@asf.alaska.edu). The satellite sensor provided high quality Earth observation data for topographic and hydrographic mapping. The threshold area for the definition of catchments was 50 ha.

\subsubsection{Stream flows and water yields}

The Fazenda Glória stream lacks a hydrometric station to measure the instream flows (If) used in Eq. (1) to calculate the water yields $\left(W_{\mathrm{y}}\right)$. To overcome this setback, the method called "Water Regionalization in the State of São Paulo" developed by the Water and Electric Energy Department of São Paulo state (DAAE; http://www.daee.sp.gov.br) provided estimates for the If. The method hinges on probabilistic and deterministic models. The computer software SIGRH2001 downloaded from the DAEE webpage automated the method. The If values were approached by the minimum stream flow in 7 consecutive days with a 10 -year return period $\left(Q_{7,10}\right)$, which were computed for every catchment in the watershed by the aforementioned software. The $\mathrm{Q}_{7,10}$ is a sanitary threshold, meaning the minimum flow capable to dilute 


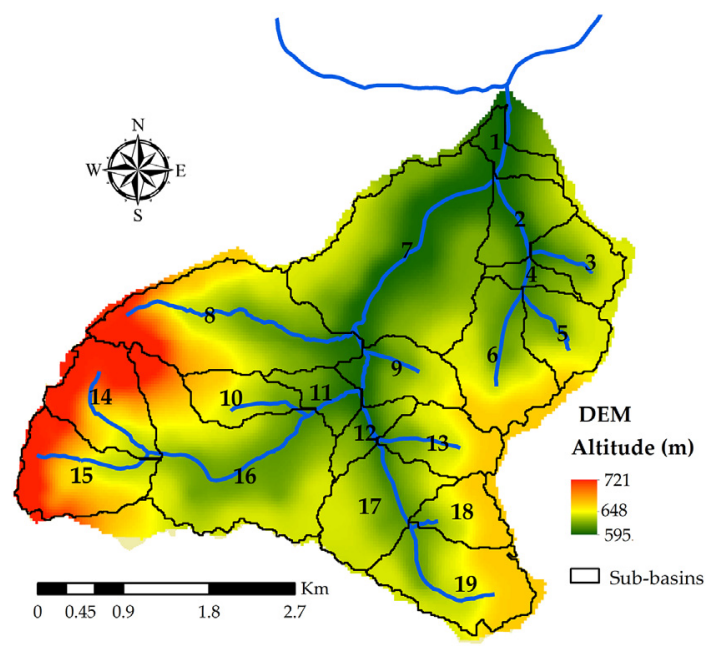

Fig. 3. Fazenda Glória watershed and tributary catchments interpreted by the ArcSWAT's "Delineate Watershed" tool as function a digital elevation model.

contaminant loads dropping their concentrations to safe levels. It is also an ecological flow capable to preserve the river's fauna and flora. It is therefore suited to integrate a PES scheme.

\subsubsection{Net income of crop production}

The digital source for crop identification and mapping was the Brazilian Institute for Geography and Statistics (https://www.ibge.gov. br). The most represented crop in the studied area was sugar cane, the reason why the net income evaluation $\left(\boldsymbol{P}_{\boldsymbol{c} p}\right)$ considered the production of this good. The São Paulo State Agriculture and Supply Secretary (https://www.agricultura.sp.gov.br), through the Institute for Agricultural Economics and the Coordination for Sustainable Rural Development, provided values for the 2019 sugar cane incomes, which were 887.0 US\$/ha/year close to the harvest.

\subsubsection{Land vulnerability}

Land vulnerability reflects the importance for natural erosion and water quality of bearing environmental attributes (geology, soil, topography and land cover), and determines the type and extent of soil-loss and water-quality control measures to undertake during the land conversions recommended by the ACWY model. The geology data source was the Geological Map of São Paulo state produced by the Instituto de Pesquisas Tecnológicas do Estado de São Paulo (IPT; https://www. ipt.br; Almeida et al., 1981). The soil data source was the Pedological Map of São Paulo state presented by Rossi (2017). The slope data derived from the DEM (Section 2.3.1). These data represent the difference between the highest and lowest elevations in the catchments, recast as percentages and assembled as relief classes. The land-use data source was the Land Use and Cover Map of São Paulo state (https://www. ibge.gov.br).

Before calculating land vulnerability ( $V_{\mathrm{u}}$; Eq. (3)), the bearing environmental attributes were rated as dimensionless parameters ( $Y$; Eq. (3)) to become comparable. A consensus among the authors derived the rating (local importance) of each geology, soil, topography and land cover class. Table 1 (column 2 ) depicts the approved values. In addition, the ranks listed in column 3 characterize the environmental attributes for their general influence over land vulnerability. In this case, the agreement among the authors set the following sequence of ranks: land cover (7) > slope (5) > soil (3) > geology (1). The well-known Analytical Hierarchy Process (AHP; Saaty, 1977) optimized the ranks producing the weights presented in the last column of Table 1 and referred to in Eq. (3). The consistency ratio for the chosen ranks was $\mathrm{CR}=0.0433(<0.1)$, meaning acceptable weights (Saaty, 1977). Having defined the weights, the equation for land vulnerability in Fazenda Glória watershed was:

$V_{u}=(0.056 G)+(0.122 S)+(0.263 S l)+(0.558 L U L C)$

where $G[-], S[-], S l[-]$ and $L U L C[-]$ represent the geology, soil, slope and land cover parameters, respectively.

\section{Results}

The "Delineate Watershed" function of ArcSWAT divided the shapefile of Fazenda Glória watershed into 19 catchments (Fig. 3). Table 2 depicts the corresponding morphometric parameters, namely area $(A)$, perimeter $(P)$, drainage length $(D l)$, altitude $(H)$, and relief amplitude $(R A)$. The catchment areas vary between $2.97 \mathrm{~km}^{2}$ and $0.20 \mathrm{~km}^{2}$, the perimeters from $3.50 \mathrm{~km}$ to $0.92 \mathrm{~km}$ and the drainage lengths from $4 \mathrm{~km}$ to $0.30 \mathrm{~km}$. The maximum altitude occurs in catchment no. 14 and reaches $722 \mathrm{~m}$. The minimum altitude occurs at the outlet catchment no. 1 and approaches $636 \mathrm{~m}$. The average relief altitudes (Max - Min altitudes) range from 37 to $125 \mathrm{~m}$

The input data and results of the ACWY model appear in Table 3 and the next figures.

The instream flows (If) approached by the $\mathrm{Q}_{7,10}$ are illustrated in Fig. 4a while the corresponding water yields (Eq. (1)) are displayed in Fig. 4b. The instream flows ranged from 20,514 to $220,752 \mathrm{~m}^{3} /$ year $\left(85,302 \mathrm{~m}^{3} /\right.$ year, on average) whereas the water yields varied from $45.62 \mathrm{~mm} /$ year to $120.23 \mathrm{~mm} /$ year meaning a 2.6-fold difference between the maximum and minimum yields. This amplitude of $W_{y}$ values makes the water service diverse among the catchments. Fig. 5a shows catchments no. 2, 7 and 13 as lower productive sectors in Fazenda Glória, with ES_W $W_{\mathrm{y}}$ values quite below the average (0.49-0.69 $<<1 \mathrm{~mm}$ /year), and catchments no. 3, 6, 10, 15 and 18 as higher productive sectors with ES_W $W_{\mathrm{y}}$ values quite above the average (1.21-1.3 > $>1 \mathrm{~mm}$ /year). According to Eq. (4), the compensation of farmers via the PES is proportional to the ES_ $W_{\mathrm{y}}$. As mentioned above, the net income for sugar cane production in 2019 was 887.00 US\$/ha/year close to the harvest, and the trade-off coefficient (Factor $X$ ) was set to 0.5 . Under these circumstances, the reference compensation to farmers is 443.5

\section{Table 2}

Morphometric parameters of Fazenda Glória watershed tributary catchments. Symbols: $A$ - area; $P$ - perimeter; $D l$ - drainage length; $H$ - altitude (Av. - Average; Min. - minimum; Max. - maximum); $R A$ - relief amplitude.

\begin{tabular}{|c|c|c|c|c|c|c|c|}
\hline \multirow[t]{2}{*}{ Catchment number } & \multirow{2}{*}{$\frac{A}{\mathrm{~km}^{2}}$} & \multirow{2}{*}{$\frac{P}{\mathrm{~km}}$} & \multirow{2}{*}{$\frac{\mathrm{Dl}}{\mathrm{km}}$} & \multicolumn{3}{|l|}{$H$} & \multirow{2}{*}{$\frac{R A}{\mathrm{~m}}$} \\
\hline & & & & Av. (m) & Min. (m) & Max. (m) & \\
\hline 1 & 0.31 & 1.40 & 0.75 & 602.4 & 582.0 & 636.0 & 54.0 \\
\hline 2 & 0.63 & 1.68 & 0.84 & 612.3 & 582.0 & 639.0 & 57.0 \\
\hline 3 & 0.54 & 1.34 & 0.68 & 628.4 & 596.0 & 647.0 & 51.0 \\
\hline 4 & 0.20 & 0.92 & 0.52 & 617.8 & 596.0 & 638.0 & 42.0 \\
\hline 5 & 0.66 & 1.36 & 0.67 & 636.1 & 601.0 & 663.0 & 62.0 \\
\hline 6 & 1.14 & 1.86 & 1.03 & 640.1 & 603.0 & 672.0 & 69.0 \\
\hline 7 & 2.97 & 3.32 & 4.00 & 614.5 & 582.0 & 651.0 & 69.0 \\
\hline 8 & 2.16 & 3.48 & 2.91 & 645.1 & 596.0 & 721.0 & 125.0 \\
\hline 9 & 0.67 & 1.51 & 0.61 & 626.1 & 596.0 & 657.0 & 61.0 \\
\hline 10 & 0.51 & 1.91 & 0.87 & 643.0 & 605.0 & 674.0 & 69.0 \\
\hline 11 & 0.36 & 1.27 & 0.61 & 612.5 & 599.0 & 636.0 & 37.0 \\
\hline 12 & 0.32 & 1.30 & 0.58 & 621.7 & 601.0 & 645.0 & 44.0 \\
\hline 13 & 0.67 & 1.52 & 0.44 & 643.1 & 606.0 & 672.0 & 66.0 \\
\hline 14 & 0.94 & 1.91 & 1.77 & 680.0 & 626.0 & 722.0 & 96.0 \\
\hline 15 & 1.07 & 1.87 & 1.45 & 674.6 & 626.0 & 718.0 & 92.0 \\
\hline 16 & 2.46 & 3.50 & 3.46 & 637.3 & 605.0 & 715.0 & 110.0 \\
\hline 17 & 1.06 & 1.89 & 1.82 & 634.9 & 605.0 & 662.0 & 57.0 \\
\hline 18 & 0.50 & 1.31 & 0.30 & 652.4 & 616.0 & 675.0 & 59.0 \\
\hline 19 & 1.19 & 2.12 & 1.44 & 648.5 & 616.0 & 680.0 & 64.0 \\
\hline Min. & 0.20 & 0.92 & 0.30 & 602.37 & 582.00 & 636.00 & 37.00 \\
\hline Max. & 2.97 & 3.50 & 4.00 & 679.97 & 626.00 & 722.00 & 125.00 \\
\hline Average & 0.97 & 1.87 & 1.30 & 635.31 & 602.05 & 669.63 & 67.58 \\
\hline
\end{tabular}


Table 3

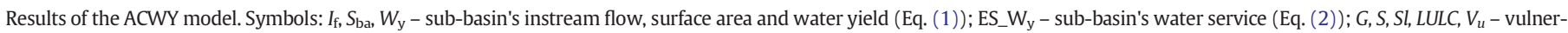

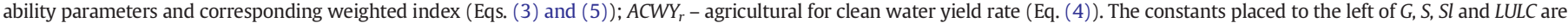
weights determined by the Analytical Hierarchy Process and used in Eq. (5).

\begin{tabular}{|c|c|c|c|c|c|c|c|c|c|c|}
\hline \multirow[t]{2}{*}{ Sub-basin } & \multirow{2}{*}{$\frac{I_{f}}{\mathrm{~m}^{3}}$} & \multirow{2}{*}{$\frac{S_{b a}}{\mathrm{~m}^{2}}$} & \multirow{2}{*}{$\frac{W_{y p}}{\mathrm{~mm} / \text { year }}$} & \multirow[t]{2}{*}{ ES_Wyp } & \multicolumn{5}{|c|}{ Vulnerability } & \multirow{2}{*}{$\frac{A C W P r}{\text { US\$/ha/year }}$} \\
\hline & & & & & $0.056 \mathrm{G}$ & $0.122 \mathrm{~S}$ & $0.263 \mathrm{Sl}$ & $0.558 \mathrm{LULC}$ & $V_{u}$ & \\
\hline 1 & 25,312 & 310,625 & 81.49 & 0.88 & 0.28 & 0.61 & 0.70 & 1.67 & 3.27 & 390.72 \\
\hline 2 & 28,725 & 629,688 & 45.62 & 0.49 & 0.28 & 0.61 & 0.71 & 1.68 & 3.28 & 218.73 \\
\hline 3 & 63,072 & 540,625 & 116.66 & 1.26 & 0.28 & 0.61 & 0.65 & 1.67 & 3.22 & 559.39 \\
\hline 4 & 20,514 & 201,719 & 101.70 & 1.10 & 0.28 & 0.61 & 0.68 & 1.67 & 3.24 & 487.61 \\
\hline 5 & 69,723 & 656,094 & 106.27 & 1.15 & 0.28 & 0.61 & 0.61 & 1.73 & 3.23 & 509.55 \\
\hline 6 & 126,144 & $1,136,094$ & 111.03 & 1.20 & 0.28 & 0.61 & 0.61 & 1.99 & 3.49 & 532.38 \\
\hline 7 & 187,000 & $2,973,594$ & 62.89 & 0.68 & 0.28 & 0.85 & 0.69 & 1.99 & 3.81 & 301.53 \\
\hline 8 & 220,752 & $2,161,250$ & 102.14 & 1.10 & 0.30 & 0.85 & 0.72 & 2.23 & 4.11 & 489.75 \\
\hline 9 & 72,545 & 670,000 & 108.28 & 1.17 & 0.28 & 0.61 & 0.65 & 2.17 & 3.71 & 519.16 \\
\hline 10 & 61,789 & 513,906 & 120.23 & 1.30 & 0.29 & 0.85 & 0.60 & 2.55 & 4.30 & 576.50 \\
\hline 11 & 27,893 & 358,438 & 77.82 & 0.84 & 0.28 & 0.85 & 0.56 & 1.97 & 3.67 & 373.13 \\
\hline 12 & 25,989 & 318,281 & 81.65 & 0.88 & 0.28 & 0.61 & 0.64 & 1.76 & 3.29 & 391.52 \\
\hline 13 & 31,256 & 672,656 & 46.47 & 0.50 & 0.28 & 0.61 & 0.68 & 2.57 & 4.14 & 222.80 \\
\hline 14 & 94,608 & 936,250 & 101.05 & 1.09 & 0.39 & 0.85 & 0.82 & 2.06 & 4.12 & 484.52 \\
\hline 15 & 126,144 & $1,073,125$ & 117.55 & 1.27 & 0.39 & 0.85 & 0.79 & 2.40 & 4.43 & 563.62 \\
\hline 16 & 157,000 & $2,461,563$ & 63.78 & 0.69 & 0.31 & 0.85 & 0.65 & 1.84 & 3.65 & 305.82 \\
\hline 17 & 97,003 & $1,057,656$ & 91.72 & 0.99 & 0.28 & 0.61 & 0.62 & 1.92 & 3.43 & 439.76 \\
\hline 18 & 57,290 & 502,969 & 113.90 & 1.23 & 0.28 & 0.61 & 0.62 & 2.39 & 3.90 & 546.15 \\
\hline 19 & 127,987 & $1,194,219$ & 107.17 & 1.16 & 0.28 & 0.61 & 0.61 & 1.71 & 3.21 & 513.87 \\
\hline Total & $1,620,746$ & $18,368,750$ & 1757.42 & 19.00 & 5.60 & 13.31 & 12.61 & 37.97 & 69.49 & 8426.50 \\
\hline Minimum & 20,514 & 201,719 & 45.62 & 0.49 & 0.28 & 0.61 & 0.56 & 1.67 & 3.21 & 218.73 \\
\hline Maximum & 220,752 & $2,973,594$ & 120.23 & 1.30 & 0.39 & 0.85 & 0.82 & 2.57 & 4.43 & 576.50 \\
\hline Average & 85,302 & 966,776 & 92.50 & 1.00 & 0.29 & 0.70 & 0.66 & 2.00 & 3.66 & 443.50 \\
\hline Standard deviation & 58,775 & 766,753 & 23.76 & 0.26 & 0.04 & 0.12 & 0.06 & 0.31 & 0.41 & 113.92 \\
\hline Variation coefficient & 69 & 79 & 25.69 & 25.69 & 11.91 & 17.19 & 9.60 & 15.35 & 11.16 & 25.69 \\
\hline
\end{tabular}

US\$/ha/year. However, considering the spatial distribution of ES_ $W_{\mathrm{y}}$ values within the Fazenda Glória watershed (Fig. 5a), the compensation adjusted to water production will range from 218.73 US\$/ha/year to 576.5 US\$/ha/year (Fig. 5b).

The spatial physiography of Fazenda Glória watershed portrayed in Figs. 6a-d integrates geology (A), soil (B), terrain slope (C) and land use/cover (D). These physiographic attributes recast as vulnerability parameters (Table 1 ) and subsequently assembled as vulnerability index (Eq. (5)) rendered $V_{\mathrm{u}}$ values in the range $2.827 \leq V_{\mathrm{u}} \leq 7.519$. The vulnerability class boundaries and corresponding impact factors (IF) are 2.827 $\leq$ Low vulnerability $($ IF $=1)<4.000,4.000 \leq$ Vulnerable $($ IF $=1.1)$ $<5.173,5.173 \leq$ High vulnerability ( $\mathrm{IF}=1.2)<6.346,6.346 \leq$ Extreme vulnerability (IF $=1.3)<7.519$. Fig. 7 shows the spatial distribution of the impact factors. As seen, all basins show a diversity of impact factors that affect the farmer's compensation relative to changing the production system. The most vulnerable catchments are 7, 8, 9, 10, 13, 14, 15 and 18 . There is no compensation in areas where IF $=1.0$. In these areas, the PES value ranges from 218.73 US\$/ha/year to $576.5 \mathrm{US \$} / \mathrm{ha}$ / year depending on the catchment's water yield, as mentioned above. The maximum compensation occurs in the extreme vulnerability areas $(\mathrm{IF}=1.3)$. In these areas the ACWYr raises 30\% concerning the water-yield adjusted range, varying from 284.35 US\$/ha/year to 749.45 US\$/ha/year.

A full conversion of intensive agriculture systems in Fazenda Glória watershed implies the payment for water services as depicted in Fig. 8. The blue bars represent the no compensation, where the

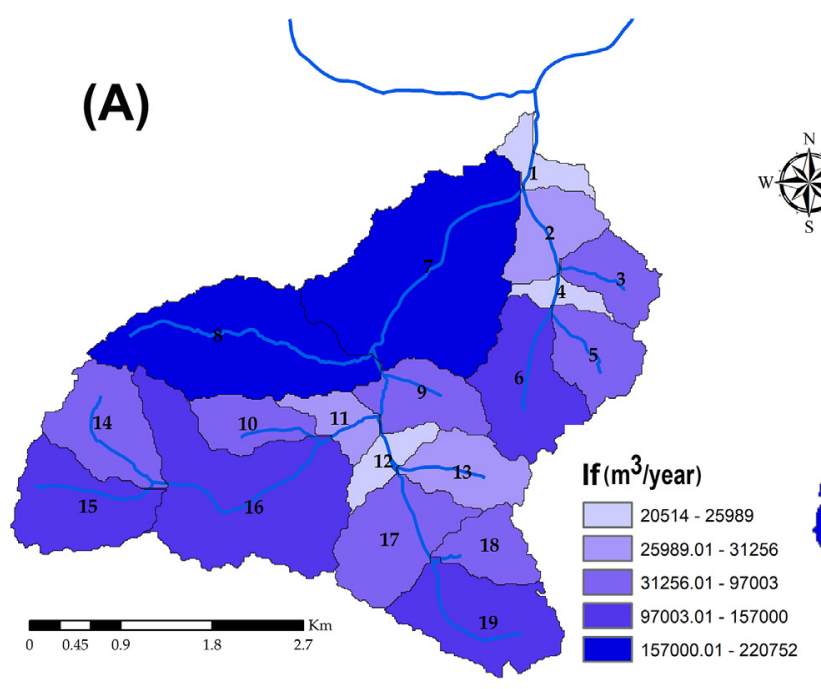

(B)

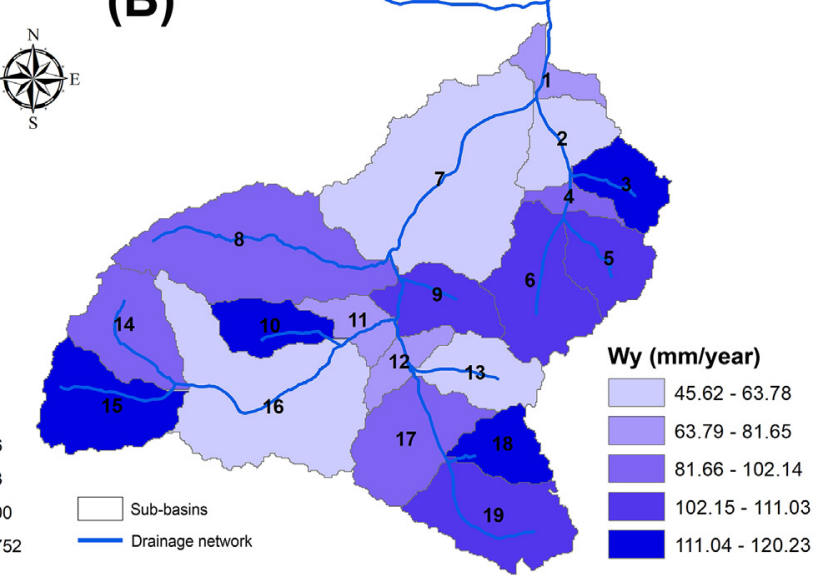

Fig. 4. (A) Instream flow (If, approached by the $Q_{7,10}$; $\left[\mathrm{m}^{3} / \mathrm{year}\right]$ ); and (B) Water yield ( $W_{\mathrm{y}}$; [mm/year]) estimated for the Fazenda Glória watershed tributary catchments. 

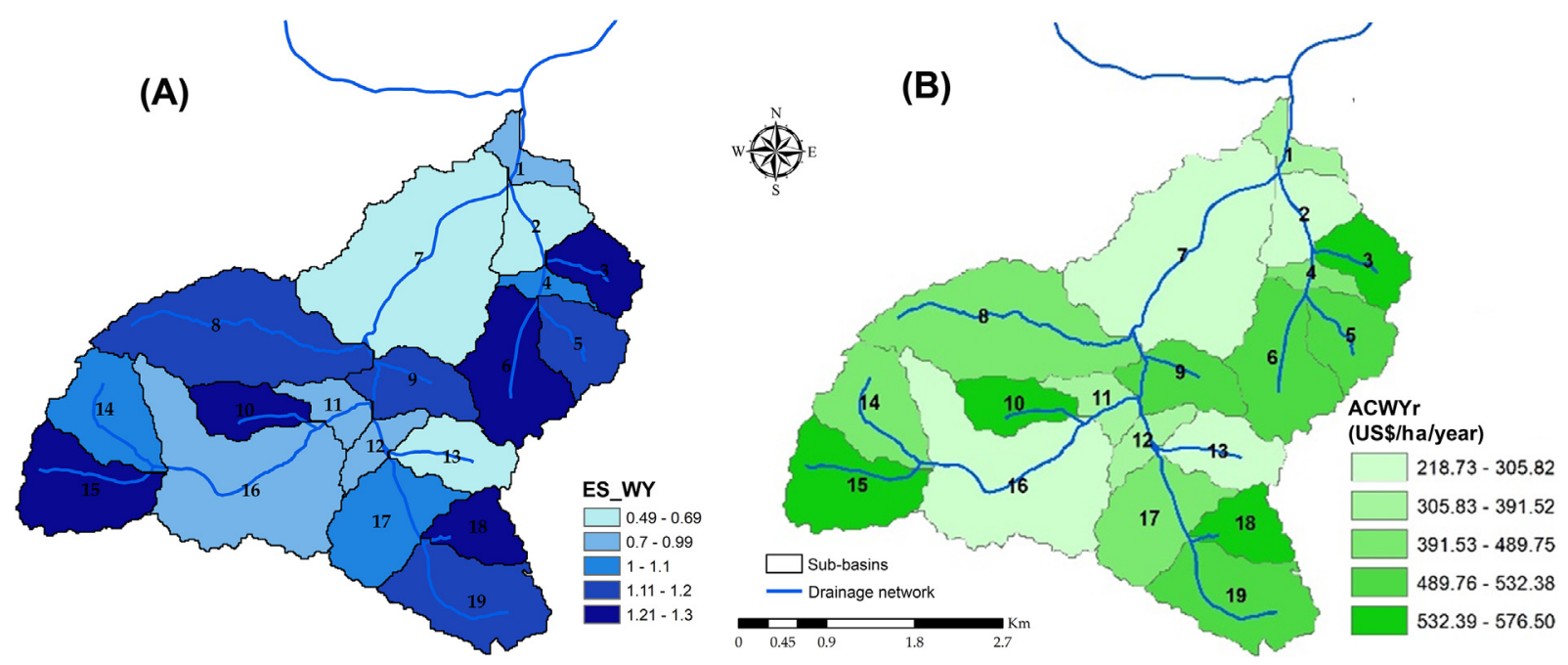

Fig. 5. (A) Water service (ES_W $W_{y}$; and (B) Agriculture for Clean Water Yield rate (ACWY ; [US\$/ha/year]) estimated for the Fazenda Glória watershed tributary catchments.

vulnerability is low (Fig. 7). The orange bars represent the maximum compensation to apply in the extreme vulnerability sectors. The actual compensation varies between these two thresholds depending on the percentage of low to extreme vulnerability areas in the catchment. The annual PES shall remain during the conversion period if the results for water quality and supply improvements are noteworthy. Beyond the conversion period, the PES can adjust to an incentive for keeping the application of best management practices, for a limited period of time.

Fig. 8 shows a wide range of ACWYr values (9836.1-105,846.7 US\$/ year; $40,901.0$ US\$/year on average), strongly influenced by the
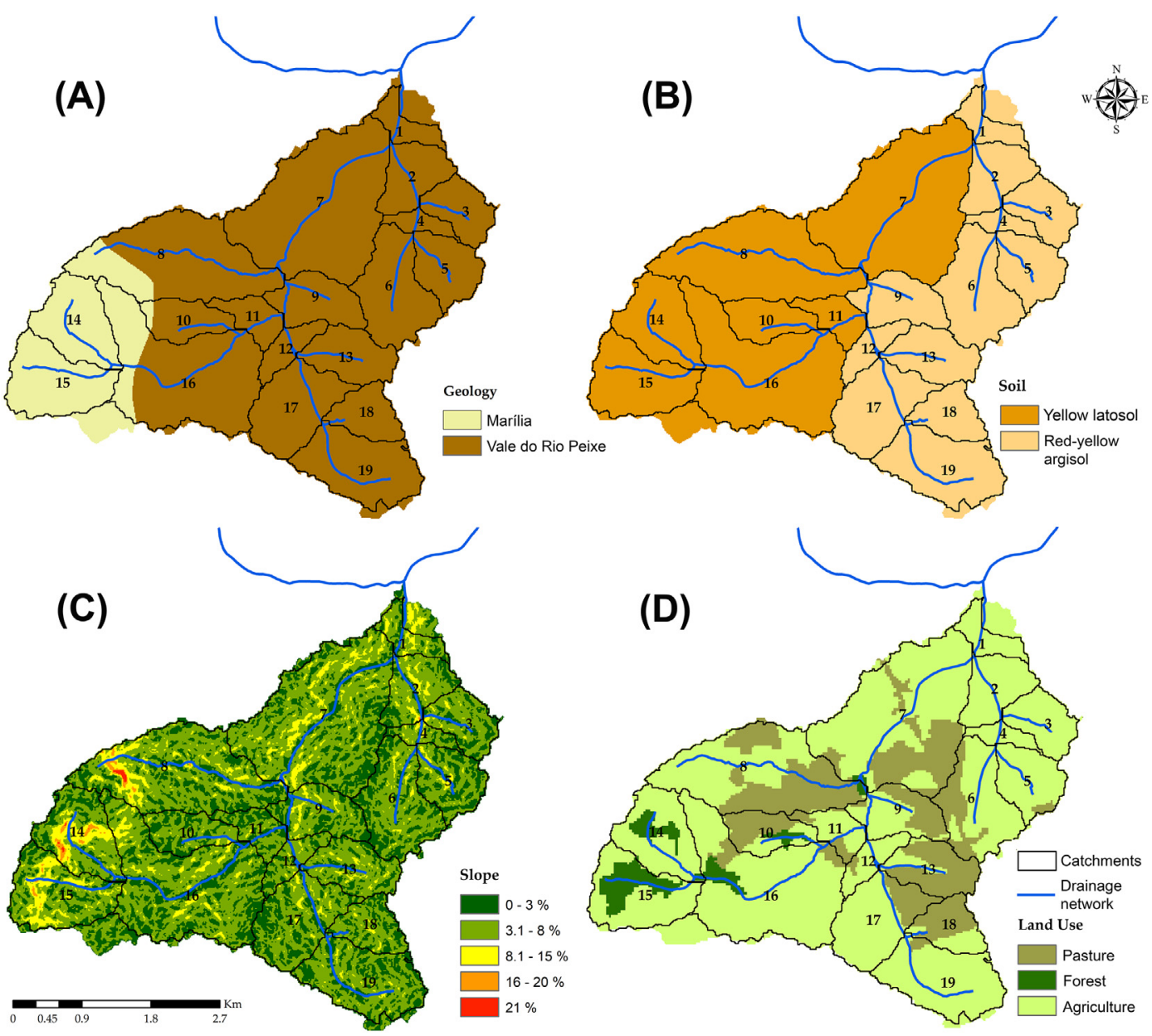

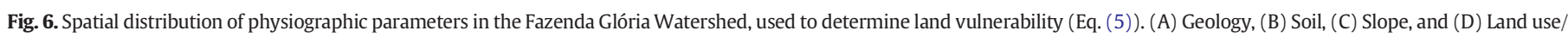
cover. 


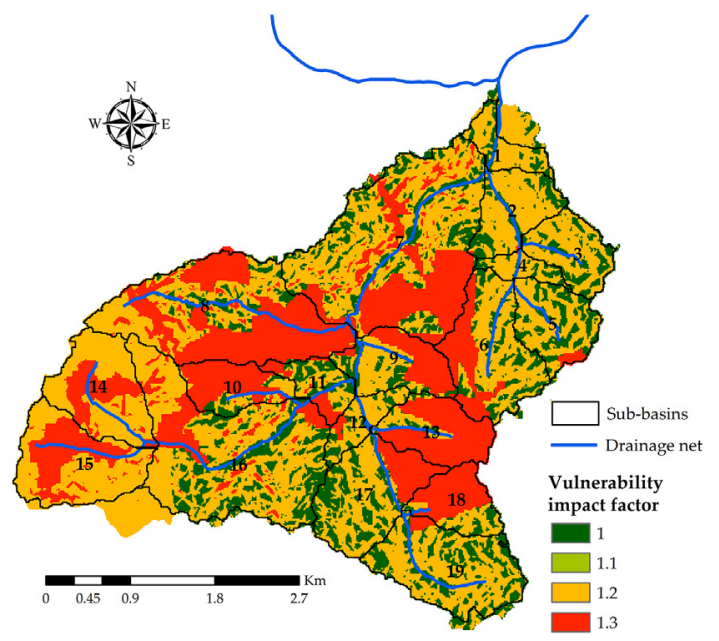

Fig. 7. Spatial distribution of vulnerability impact factors in Fazenda Glória watershed.

catchment area, besides the contributions of water yield capacity and land vulnerability.

\section{Discussion}

The Agriculture for Clean Water Yield (ACWY) model is a financial incentive strategy to promote better management practices in a rural area and maximize water provision services for multiple uses including drinking water. The model offers the necessary instruments to analyze better agricultural scenarios (Faria and Haddad, 2019) that require cost-sharing rules (Bellver-Domingo et al., 2016; Fan and Chen, 2019; Geussens et al., 2019). Adopting the ACWY model ensures acceptable cost allocations that consider water and sustainable agricultural production systems in watersheds (Fu et al., 2018; Tsur, 2020) and it is of fundamental importance on agricultural-water-related sustainability issues when applied to water and soil management.

The model applied to Fazenda Glória watershed composed of 19 headwater catchments (Fig. 3) estimated a compensation for farmers valued according to the catchments' water yields (Fig. 4b). Starting from a potential compensation indexed to half the net income of crop production (443.5 US\$/ha/year for sugar cane in 2019, the prominent culture in the region), farmers obtain the actual financial incentive multiplying that value by a factor in the range $0.49-1.3$ depending on the water service provided by the cultivated catchment (Fig. $5 a$ ). In the studied area, the incentive adjusted this way varied from 218.73 US\$/ ha/year to 576.50 US\$/ha/year (Fig. 5b). The link of a financial incentive to a coupled agricultural and water production is novel in the literature. The study of Haavisto et al. (2019) discussed the payment for water services in agricultural areas. However, the purpose was to determine the optimal share among the allocation to irrigation and drinking water at municipal scale. In this case, the farmers would receive a financial support to compensate crop yield reductions caused by irrigation water shortages. The study of Maneta et al. (2020) followed a similar rationale, but aimed to provide water authorities with remote sensed data and hydro-economic models capable to anticipate how farmers allocate water and cropland when confronted with new policy rules, climate patterns or competing interests. Similar studies conducted in various agricultural regions discussed water and land allocation for irrigation purposes (e.g., Parrado et al., 2020; Sapino et al., 2020), but were not interested in managing agriculture as to improve water services for other uses namely drinking water.

The Fazenda Glória headwater basin produces sugar cane under intensive regime, which is unsustainable, severely amplifies soil erosion, and negatively affects the quality of drinking water supplied to the Jaboticabal city. The ACWY model indicated the amount to pay rural producers (Fig. 8) so they shift from the intensive production system to an agro-forestry landscape aiming the control of erosion and the return of water quality to a clean status. The maximum incentives ranged from 284.35 US\$/ha/year to 749.45 US\$/ha/year depending on land vulnerability (Fig. 7). In a study addressing the conversion of cornsoybeans to switchgrass land use aiming to promote reduction of nitrate pollution in the Chesapeake Bay (USA) and complementary produce biofuel, Li and Zipp (2019) estimated targeted PES values between 35 and 390 US\$/ha depending on actual pollution alleviation. The Sloping Land Conversion Program initiated by the Chinese government in the late 1990s had the purpose to combat erosion, droughts and floods, namely in the Yellow and Yangtze rivers. By the end of 2012, 9.26 million hectares of sloping agricultural land had been converted to forest while the total compensation payments amounted to 5600 US $\$ /$ ha (Liu and Henningsen, 2016). These contrasting results show that conversion costs related with agriculture are not comparable among cases because they depend considerably on the local environmental settings

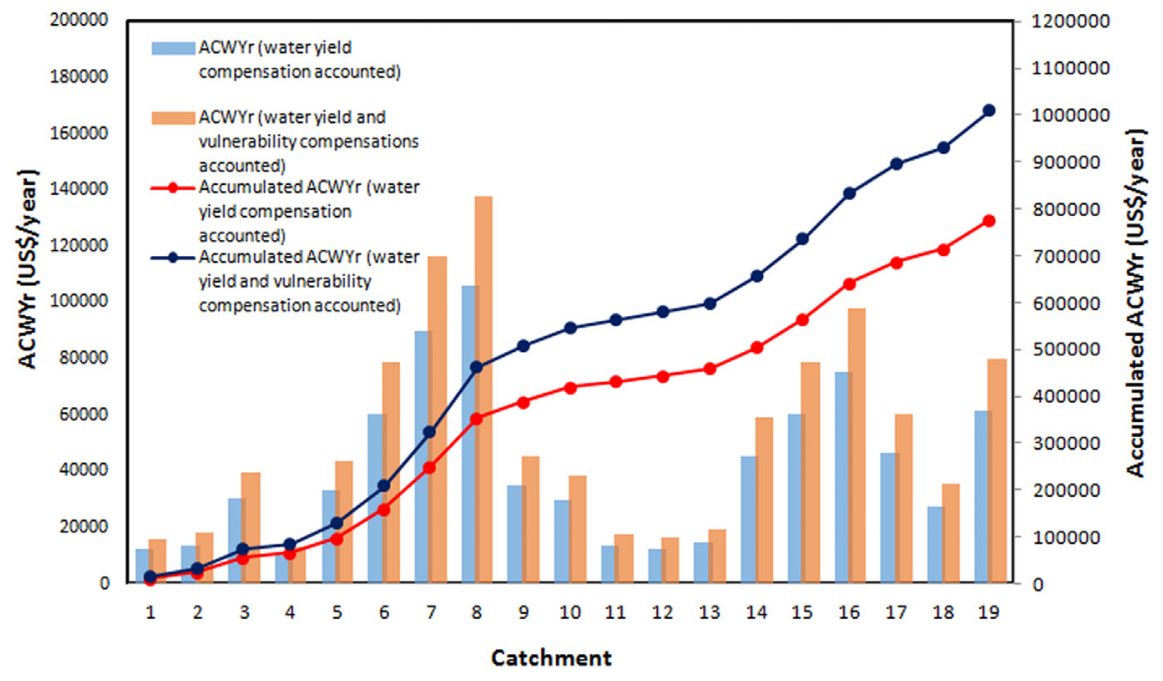

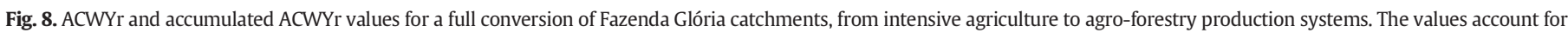
water yield capacity and conversion costs influenced by catchment area and landscape vulnerability. 
and the specific conversion purposes. However, the ACWY model transposes to any region around the globe providing that water yield, crop prices, trade-off coefficients (Factor $X$ ), land vulnerability and concomitant impact factors adjust to the new area.

The monitoring of land conversion for performance (i.e., water quality and yield improvements) shall determine the compensation value dynamically under the risk of PES failure in the long term (de Lima et al., 2019). Besides, imposing limits to the PES period is important to avoid unjustified rents for farmers and cost to the society (Calle, 2020). The ACWY model discriminates the incentive related with the land conversion, inherently linked to landscape vulnerability, from the incentive related with the reduction of cropland and consequent crop yield. In Fazenda Glória, farmers should receive the two parcels (i.e., 284.35-749.45 US\$/ha/year) during a reasonable time necessary to perform the land conversion (e.g., 2-3 years). Beyond that period, farmers should receive the second parcel (i.e., 218.73-576.50 US\$/ha/ year) during some extra time (e.g., 1-2 years), to ensure continued implementation of best management practices and as motivation for farmers to raise crop yields in the agro-forestry system to preconversion levels, e.g. through technological improvements. In both periods, the compensation will be due if effective water quality and yield improvements are attained. We do not rule out that in countries like Brazil with large areas associated to head water basins, where intensive agriculture is an important economic sector, the proposed ACWY model may retard the economic growth of the country. In this line, from a pragmatic point of view, other engineering options for producing clean water (e.g., water treatment/purification plants) might complement the PES scheme despite being not so attractive from an environmental point of view.

The success of a PES program depends on political will, a realistic PES design and available funds for the compensations (Kolinjivadi et al., 2014; Zanella et al., 2014). This is frequently unaccomplished, in which cases the PES is doomed to failure. For example, the Brazilian's new Forest Code, Article 41 (Brasil, 2012), imposes on the Federal executive the obligation to elaborate a program supporting and promoting the conservation of environment. Furthermore, it encourages the adoption of technologies and good practices that combine agricultural and forestry production with the reduction of environmental impacts as a way of enabling ecologically sustainable development. Despite this legal enforcement, there is no apparent mobilization within the Federal authorities to develop such a program (Azevedo et al., 2017). This may be discouraging to implement the ACWY in Fazenda Glória watershed, despite the resolutions focused on water services and their payment recently enforced by the São State Secretariat of Environment (SEMA, 2015, 2016). However, if water planners decide upon its application in the future beneficiaries must support the landowner (agricultural producer). Among others, this includes water supply companies, an incentive fund for sustainable agricultural production, or a water bank credit. The taxation of water users for the credit bank formation has direct implications for water tax policy, water law, and water economics to evaluate whether taxation of water consumption for this purpose makes sense. This is especially pertinent in Brazil, where each state has its own water tax policy. Future studies must therefore compare how sources and schemes of financial incentive compare among each other concerning their ability to support a PES scheme aiming the valuation of water yielding from headwater catchments. Future work must also discuss the impact of climate change on the application of ACWY model, since the payment for the water service indexes to headwater yield capacity. For example, in Kentucky (USA) the combined effect of forestation and precipitation increase has raised the water retention from 12.78 billion $\mathrm{m}^{3}$ in 1992 to 21.11 billion $\mathrm{m}^{3}$ in 2011 (i.e., 65.19\%) as noted by Bai et al. (2019). The results obtained by Ferreira et al. (2019) for the Tietê River basin and São Paulo megalopolis (Brazil) confirmed the impact of climate and land use changes on water-related services, corroborating the need to adapt the ACWY model and the PES to predictable global changes.

\section{Conclusions}

The Agriculture for Clean Water Yield (ACWY) model applied to Fazenda Glória watershed, a headwater basin located in São Paulo state (Brazil), revealed the possible coexistence of agriculture production and clean water yield at a land conversion price. Conversion of agriculture production systems is mandatory when they are intensive and repeatedly damage stream water quality. In this case, the best trajectory for crop production and livestock pasturing in a healthy environment (sustainable agriculture) is through conversion of intensively cultivated land into agroforestry systems where a mosaic of croplands, pastures and forests dominate the landscape and catchments discharge quality water.

The conversion of land is the trajectory to produce food in a clean headwater catchment but its realization depends on a financial support. Farmers could be charged to implement the conversion following the "polluter pays" principle. However, the ACWY model adopted the incentive approach whereby the demanders of clean water pay the conversion, while that money returns to farmers as compensation for changing the land use pattern. The approach makes sense because food production is vital for humans, regardless the potential impacts derived therefrom. Thus, the ACWY model estimated a minimum compensation in the interval 218.73-576.5 US\$/ha/year. This ample range is justified because farmers converting larger-yield catchments must receive more than those converting smaller-yield catchments. The model also accounted for the challenge of converting catchments located in extreme vulnerable catchments, namely prone to erosion and nutrient leaching. In these cases the compensation raised to 284.35-749.45 US\$/ha/year. In all cases, the reference for the compensation was the 2019's net income of farmers producing sugar cane in the watershed (887 US\$/ha/year), the prominent culture in the region. Besides, the ACWY presupposes a finite implementation timeframe, conceived as period to change farmers' behavior. To ensure a good performance during the implementation period monitoring must be continuous and predict flexible compensation that will rise and drop depending on the expected results (improved quality and supply).

The ACWY promises realistic outcomes. However, despite the legal support by Federal and State laws, including the new Brazilian's Forest code, the implementation of models like the ACWY (a payment for ecosystem services) is still incipient in the region and the country. The financial sources to support a project based on the ACWY model are still uncertain as well. We hope this study has contributed to provide new insights about the rationale, the costs involved and the operational boundaries of ACWY model, and that clean water returns to Fazenda Glória watershed soon.

\section{CRediT authorship contribution statement}

Teresa Cristina Tarlé Pissarra: Conceptualization, Methodology, Investigation, Formal analysis, Data curation, Writing - original draft, Visualization. Luis Filipe Sanches Fernandes: Validation, Supervision, Project administration, Resources. Fernando Antonio Leal Pacheco: Validation, Supervision, Project administration, Resources, Writing review \& editing.

\section{Declaration of competing interest}

The authors declare that they have no known competing financial interests or personal relationships that could have appeared to influence the work reported in this paper.

\section{Acknowledgments}

The present study complies with the Postdoctoral studies of Prof. Teresa Cristina Tarlé Pissarra developed in the University of Trás-osMontes and Alto Douro (UTAD), under the Proc. No. 72 659, in accordance with UTAD's Postdoctoral Regulation (Reg. No. 467/2019, 
published in Diário da República $n^{\circ} 28$ of May 2019). It also frames within the working plan of Land Use Policy Brazilian Group (POLUS). For the author integrated in the CITAB Research Centre, the research was financed by the National Funds of FCT-Portuguese Foundation for Science and Technology, under the project UIDB/04033/2020. For the author integrated in the CQVR, the research was financed by the National Funds of FCT-Portuguese Foundation for Science and Technology, under the project UIDB/00616/2020. The authors wish to thank the help of Prof. Anildo Monteiro Caldas from Pernambuco's Federal Rural University, and Prof. Renata Cristina Araújo Costa from the Guarulhos University, for their constructive remarks on the methodology and help in the production of maps.

\section{References}

Alavalapati, J.R.R., Mercer, D.E. (eds), 2004. Valuing Agroforestry Systems: Methods and Applications. Advances in Forestry, vol. 2, Klewer Academic Publishers, Dordrecht, The Netherlands, $314 \mathrm{pp}$.

Alcon, F., Marín-Miñano, C., Zabala, J.A., de Miguel, M.D., Martínez-Paz, J.M., 2020. Valuing diversification benefits through intercropping in Mediterranean agroecosystems: a choice experiment approach. Ecol. Econ. 171, 106593.

Almeida, F.F.M. (et al)., 1981. Mapa Geológico do Estado de São Paulo. Nota Explicativa, vol. 1, 126p. IPT - Instituto de Pesquisas Tecnológicas, São Paulo.

Alves-Pinto, H.N., Latawiec, A.E., Strassburg, B.B.N., Barros, F.S.M., Sansevero, J.B.B., Iribarrem, A., Crouzeilles, R., Lemgruber, L., Rangel, M.C., Silva, A.C.P., 2017. Reconciling rural development and ecological restoration: strategies and policy recommendations for the Brazilian Atlantic Forest. Land Use Policy 60, 419-426.

Andrade, E.M., Guerreiro, M.J.S., Palácio, H.A.Q., Campos, D.A., 2020. Ecohydrology in a Brazilian tropical dry forest: thinned vegetation impact on hydrological functions and ecosystem services. Journal of Hydrology: Regional Studies 27, 100649.

Araújo, R.S., Chrispim, Z.M.P., 2017. Anthropic actions in the environment: the idea of “environmental underdevelopment". Environ Pollut Climate Change 1 (126), 2.

Azevedo, A.A., Rajão, R., Costa, M.A., Stabile, M.C.C., Macedo, M.N., dos Reis, T.N.P., Alencar, A., Soares-Filho, B.S., Pacheco, R., 2017. Limits of Brazil's Forest Code as a means to end illegal deforestation. Proc. Natl. Acad. Sci. 114, 7653-7658.

Bai, Y., Wang, R., Jin, J., 2011. Water eco-service assessment and compensation in a coal mining region: a case study in the Mentougou District in Beijing. Ecol. Complex. 8 (2), 144-152.

Bai, Y., Ochuodho, T.O., Yang, J., 2019. Impact of land use and climate change on waterrelated ecosystem services in Kentucky, USA. Ecol. Indic. 102, 51-64.

Begossi, A., May, P.H., Lopes, P.F., Oliveira, L.E., Da Vinha, V., Silvano, R.A., 2011. Compensation for environmental services from artisanal fisheries in SE Brazil: policy and technical strategies. Ecol. Econ. 71, 25-32.

Bellver-Domingo, A., Hernández-Sancho, F., Molinos-Senante, M., 2016. A review of Payment for Ecosystem Services for the economic internalization of environmental externalities: a water perspective. Geoforum 70, 115-118.

Brasil, 2012. Law 12651/2012. Brazilian Forest Code. http://www.planalto.gov.br.

Burkhard, B., Kroll, F., Nedkov, S., Müller, F., 2012. Mapping ecosystem service supply, demand and budgets. Ecol. Indic. 21, 17-29.

Calle, A., 2020. Can short-term payments for ecosystem services deliver long-term tree cover change? Ecosyst. Serv. 42, 101084

Camargo, M.N., Klamt, E., Kauffman, J.H., 1987. Classificação de solos usada em levantamentos pedológicos no Brasil. Revista Brasileira de Ciência do Solo 12, 11-33.

Canova, M.A., Lapola, D.M., Pinho, P., Dick, J., Patricio, G.B., Priess, J.A., 2019. Different ecosystem services, same (dis) satisfaction with compensation: a critical comparison between farmers' perception in Scotland and Brazil. Ecosystem services 35, 164-172.

Cheng, B., Li, H., Yue, S., Huang, K., 2019. A conceptual decision-making for the ecological base flow of rivers considering the economic value of ecosystem services of rivers in water shortage area of Northwest China. J. Hydrol. 578, 124126.

Costa, R.C.A., Pereira, G.T., Tarlé Pissarra, T.C., Silva Siqueira, D., Sanches Fernandes, L.F., Vasconcelos, V., Fernandes, L.A., Pacheco, F.A.L., 2019. Land capability of multiplelandform watersheds with environmental land use conflicts. Land Use Policy 81, 689-704.

de Lima, L.S., Ramos Barón, P.A., Villamayor-Tomas, S., Krueger, T., 2019. Will PES schemes survive in the long-term without evidence of their effectiveness? Exploring four water-related cases in Colombia. Ecol. Econ. 156, 211-223.

de Moraes, M.C.P., de Mello, K., Toppa, R.H., 2017. Protected areas and agricultural expansion: biodiversity conservation versus economic growth in the southeast of Brazil. J. Environ. Manag. 188, 73-84.

de Sartre, X.A., Oszwald, J., Veiga, I., Castro, M., de Assis, W.S., Michelloti, F., Rocha, C., Souza, H., Sebille, P., Dolédec, S., Lavelle, P., 2016. Sustainable development policies and the spread of land-sharing practices - a statistical assessment in a frontier region of the Brazilian Amazon. J. Rural. Stud. 48, 65-76.

Donadio, N.M.M., Galbiatti, J.A., Paula, R.C., 2005. Qualidade da água de nascentes com diferentes usos do solo na bacia hidrográfica do Córrego Rico, São Paulo, Brasil. Eng. Agríc. Jaboticabal 25 (1), 115-120.

Duffy, C., O’Donoghue, C., Ryan, M., Kilcline, K., Upton, V., Spillane, C., 2020. The impact of forestry as a land use on water quality outcomes: an integrated analysis. For. Policy Econ. 116, 102185

Fan, M., Chen, L., 2019. Spatial characteristics of land uses and ecological compensations based on payment for ecosystem services model from 2000 to 2015 in Sichuan Province, China. Ecological Informatics 50, 162-183.
Faria, W.R., Haddad, E.A., 2019. Modelagem do uso da Terra e Efeitos de Mudanças na Produtividade Agrícola entre 2008 e 2015. Estud. Econômicos (São Paulo) 49, 65-103.

Fernandes, L.A., Coimbra, A.M., 2000. Revisão estratigráfica da parte oriental da Bacia Bauru (Neocretáceo). Revista Brasileira de Geociências 30 (4), 717-728.

Fernandes, L.A., Coimbra, A.M.A., 1996. Bacia Bauru (Cretáceo Superior, Brasil). An. Acad. Bras. Cienc. 68 (2), 195-205.

Ferreira, P., van Soesbergen, A., Mulligan, M., Freitas, M., Vale, M.M., 2019. Can forests buffer negative impacts of land-use and climate changes on water ecosystem services? The case of a Brazilian megalopolis. Sci. Total Environ. 685, 248-258.

Fu, Y., Zhang, J., Zhang, C., Zang, W., Guo, W., Qian, Z., Liu, L., Zhao, J., Feng, J., 2018. Payments for ecosystem services for watershed water resource allocations. J. Hydrol. 556, 689-700.

Geussens, K., Van den Broeck, G., Vanderhaegen, K., Verbist, B., Maertens, M., 2019. Farmers' perspectives on payments for ecosystem services in Uganda. Land Use Policy 84, 316-327.

Ghaley, B.B., Vesterdal, L., Porter, J.R., 2014. Quantification and valuation of ecosystem services in diverse production systems for informed decision-making. Environ. Sci. Pol. 39, 139-149.

Gutzler, C., Helming, K., Balla, D., Dannowski, R., Deumlich, D., Glemnitz, M., Knierim, A Mirschel, W., Nendel, C., Paul, C., Sieber, S., Stachow, U., Starick, A., Wieland, R. Wurbs, A., Zander, P., 2015. Agricultural land use changes - a scenario-based sustainability impact assessment for Brandenburg. Germany. Ecol. Indic. 48, 505-517.

Haavisto, R., Santos, D., Perrels, A., 2019. Determining payments for watershed services by hydro-economic modeling for optimal water allocation between agricultural and municipal water use. Water Resour. Econ. 26, 100127.

Haile, K.K., Tirivayi, N., Tesfaye, W., 2019. Farmers' willingness to accept payments for ecosystem services on agricultural land: the case of climate-smart agroforestry in Ethiopia. Ecosyst. Serv. 39, 100964.

Hirata, R., Suhogusoff, A., Fernandes, A., 2007. Groundwater Resources in the State of São Paulo (Brazil): The Application of Indicators.

IBGE - Instituto Brasileiro de Geografia e Estatística, 2010. Censo Demográfico 2010. Available at: http://www.censo2010.ibge gov.br. Accessed in: 31 March, 2020.

Jones, K.W., Powlen, K., Roberts, R., Shinbrot, X., 2020. Participation in payments for ecosystem services programs in the Global South: a systematic review. Ecosyst. Serv. 45, 101159 .

Kolinjivadi, V., Adamowski, J., Kosoy, N., 2014. Recasting payments for ecosystem services (PES) in water resource management: a novel institutional approach. Ecosyst. Serv. $10,144-154$

Koschke, L., Fürst, C., Frank, S., Makeschin, F., 2012. A multi-criteria approach for an integrated land-cover-based assessment of ecosystem services provision to support landscape planning. Ecol. Indic. 21, 54-66.

Lampert, A., Hastings, A., 2019. How to combine two methods to restore populations cost effectively. Ecosphere 10(1), article e02552. https://doi.org/10.1002/ecs2.2552.

Li, X., Zipp, K.Y., 2019. Dynamics and uncertainty in land use conversion for perennial energy crop production: exploring effects of payments for ecosystem services policies. J. Agric. Resour. Econ. 48, 328-358.

Liu, D., Guo, S., Shao, Q., Liu, P., Xiong, L., Wang, L., Hong, X., Xu, Y., Wang, Z., 2018 Assessing the effects of adaptation measures on optimal water resources allocation under varied water availability conditions. J. Hydrol. 556, 759-774.

Liu, Z., Henningsen, A., 2016. The effects of China's sloping land conversion program on agricultural households. Agric. Econ. 47, 295-307.

Lopes, L.G., Marchi, M.R.R., Souza, J.B.G., Moura, J.A., Lorenzon, C.S., Cruz, C., Amaral, L.A., 2010. Estrogênios em águas naturais e tratadas da região de Jaboticabal - São Paulo. Quim Nova 33, 639-643.

Maes, J., Liquete, C., Teller, A., Erhard, M., Paracchini, M.L., Barredo, J.I., Grizzetti, B., Cardoso, A., Somma, F., Petersen, J.E., Meiner, A., Gelabert, E.R., Zal, N., Kristensen, P., Bastrup-Birk, A., Biala, K., Piroddi, C., Egoh, B., Degeorges, P., Fiorina, C., SantosMartín, F., Naruševičius, V., Verboven, J., Pereira, H.M., Bengtsson, J., Gocheva, K. Marta-Pedroso, C., Snäll, T., Estreguil, C., San-Miguel-Ayanz, J., Pérez-Soba, M., GrêtRegamey, A., Lillebø, A.I., Malak, D.A., Condé, S., Moen, J., Czúcz, B., Drakou, E.G., Zulian, G., Lavalle, C., 2016. An indicator framework for assessing ecosystem services in support of the EU Biodiversity Strategy to 2020. Ecosystem Services 17, 14-23.

Maneta, M.P., Cobourn, K., Kimball, J.S., He, M., Silverman, N.L., Chaffin, B.C., Ewing, S., Ji, X., Maxwell, B., 2020. A satellite-driven hydro-economic model to support agricultural water resources management. Environ. Model. Softw. 134, 104836.

MEA - Millennium Ecosystem Assessment, 2005. Ecosystems and Human Well-being: Synthesis. Island Press, Washington, DC. Copyright (C 2005 World Resources Institute. https://www.millennium assessment. org/en/index.html.

Ola, O., Menapace, L., Benjamin, E., Lang, H., 2019. Determinants of the environmental conservation and poverty alleviation objectives of Payments for Ecosystem Services (PES) programs. Ecosystem services 35, 52-66.

Oliveira, C.F., do Valle Junior, R.F., Valera, C.A., Rodrigues, V.S., Fernandes, L.F.S., Pacheco, F.A.L., 2019. The modeling of pasture conservation and of its impact on stream water quality using Partial Least Squares-Path Modeling. Sci. Total Environ. 697, 134081.

Oliveira, J.B., 1999. Mapa de Solos do Estado de São Paulo: descrição das classes registradas no mapa pedológico. Boletim Científico 45, 112p. Campinas, Instituto Agronômico.

Pacheco, F.A.L., Sanches Fernandes, L.F., 2016. Environmental land use conflicts in catchments: a major cause of amplified nitrate in river water. Sci. Total Environ. 548-549, 173-188.

Pacheco, F.A.L., Varandas, S.G.P., Sanches Fernandes, L.F., Valle Junior, R.F., 2014. Soil losses in rural watersheds with environmental land use conflicts. Sci. Total Environ. 485-486, 110-120. 
Pacheco, F.A.L., Fernandes, L.F.S., Junior, R.F.V., Valera, C.A., Pissarra, T.C.T., 2018. Land degradation: Multiple environmental consequences and routes to neutrality. Current Opinion in Environmental Science \& Health 5, 79-86.

Parkhurst, G.M., 2013. Payments for ecosystem services: mechanisms to achieve desired landscape patterns, in: Encyclopedia of Energy, Natural Resource, and Environmental Economics. Elsevier, pp. 68-74.

Parrado, R., Pérez-Blanco, C.D., Gutiérrez-Martín, C., Gil-García, L., 2020. To charge or to cap in agricultural water management. Insights from modular iterative modeling for the assessment of bilateral micro-macro-economic feedback links. Sci. Total Environ. 742, 140526

Pinto, F.R., 2011. Qualidade da água em propriedades rurais da microbacia hidrográfica do Córrego Rico, Jaboticabal - SP. PhD Thesis, Universidade Estadual Paulista "Julio De Mesquita Filho", Faculdade de Ciências Agrárias e Veterinárias, Campus De Jaboticabal, 139p.

Power, A.G., 2010. Ecosystem services and agriculture: tradeoffs and synergies. Philos. Trans. R. Soc. B Biol. Sci. 365, 2959-2971.

Ribeiro, F.L., Campos, S., 2007. Vulnerabilidade à erosão do solo da região do Alto Rio Pardo, Pardinho. SP. Rev. Bras. Eng. Agrícola e Ambient. 11, 628-636.

Rodrigues, F.M., Pissarra, T.C.T., Campos, S., Migliaccio, K.W., 2013. Rodrigues, CTA. Mapping for environmental planning the basin of Córrego Rico. São Paulo. Journal of Hyperspectral Remote Sensing 3 (3), 45-58.

Rossi, M., 2017. Mapa pedológico do Estado de São Paulo: revisado e ampliado. São Paulo: Instituto Florestal, 2017. V.1. 118p. (inclui Mapas).

Ruffo, S., Kareiva, P.M., 2009. Using science to assign value to nature. Front. Ecol. Environ. 7 (1), 3-60.

Saaty, T.L., 1977. A scaling method for priorities in hierarchical structures. J. Math. Psychol. 15 (3), 234-281.

Sagoff, M., 2011. The quantification and valuation of ecosystem services. Ecol. Econ. 70 (3), 497-502.

Santos, L.J.C., Oka-Fiori, C., Canalli, N.E., Fiori, A.P., da Silveira, C.T., da Silva, J.M.F., 2016. Mapeamento da vulnerabilidade geoambiental do estado do Paraná. Revista Brasileira de Geociências 37 (4), 812-820.

Sapino, F., Pérez-Blanco, C.D., Gutiérrez-Martín, C., Frontuto, V., 2020. An ensemble experiment of mathematical programming models to assess socio-economic effects of agricultural water pricing reform in the Piedmont region. Italy. J. Environ. Manage. 267, 110645.

Saran, L.M., Pissarra, T.C.T., Silveira, G.A., Constancio, M.T.L., de Melo, W.J., Alves, L.M.C., 2018. Land use impact on potentially toxic metals concentration on surface water and resistant microorganisms in watersheds. Ecotoxicol. Environ. Saf. 166, 366-374.

Scholten, C., Lopes, L.G., Amaral, L.A., 2012. Fecal pollution dynamics of Córrego Rico stream and supply water of Jaboticabal city-SP. ARS Veterinaria, Jaboticabal-SP 28 (3), 177-184

Sedghamiz, A., Nikoo, M.R., Heidarpour, M., Sadegh, M., 2018. Developing a noncooperative optimization model for water and crop area allocation based on leaderfollower game Journal of Hydrology 567, 51-59.

SEMA - Secretaria de Estado do Meio Ambiente, 2015. Resolução SMA n 19, de 07 de abril de 2015. Cria o projeto de Pagamentos por Serviços Ambientais Mata Ciliar, no âmbito do Programa de Nascentes. 1-7.

SEMA - Secretaria de Estado do Meio Ambiente, 2016. Resolução SMA no. 60, de 01 de Julho de 2016, Altera dispositivos da Resolução SMA n 19, de 07 de abril de 2015, que cria o projeto de Pagamentos por Serviços Ambientais Mata Ciliar, no âmbito do Programa de Nascentes.

Settre, C.M., Connor, J.D., Wheeler, S.A., 2019. Emerging water and carbon market opportunities for environmental water and climate regulation ecosystem service provision. J. Hydrol. 578, 124077.

Sheng, J., Webber, M., 2017. Incentive-compatible payments for watershed services along the Eastern Route of China's South-North Water Transfer Project. Ecosystem Services $25,213-226$.

SIGRH - Sistema Integrado de Gerenciamento dos Recursos Hídricos, 2020. CBH-MOGI Comitê da Bacia Hidrográfica do Rio Mogi Guaçu. Coordenadoria de Recursos Hídricos. Available at: http://www.sigrh.sp.gov.br/cbhmogi/apresentacao. Accessed in: May 4, 2020

Silva, L.J., Lopes, L.G., Amaral, L.A., 2016. Quality of public-supply water in Jaboticabal city, Brazil. Revista Engenharia Sanitária e Ambiental 21 (3), 615-622.

Thomson, K., Kerle, S., Waylenk, K., Martin-Ortega, J., 2014. Water-based payment for ecosystem services (PES) schemes in Scotland. Reconciling Theory and Practice 69 (6), 1202-1208.

Tsur, Y., 2020. Optimal water pricing: accounting for environmental externalities. Ecol. Econ. 170, 106429.

Valle Junior, R.F. do, Varandas, S.G.P., Fernandes, L.S., Pacheco, F.A.L., 2014a. Environmental land use conflicts: a threat to soil conservation. Land Use Policy 41, 172-185.

Valle Junior, R.F. do, Varandas, S.G., Pacheco, F.A., Pereira, V.R., Santos, C.F., Cortes, R.M. Fernandes, L.F.S., 2015. Impacts of land use conflicts on riverine ecosystems. Land Use Policy 43, 48-62.

Valle Junior, R.F., Varandas, S.G.P., Sanches Fernandes, L.F., Pacheco, F.A.L., 2014b. Groundwater quality in rural watersheds with environmental land use conflicts. Sci. Total Environ. 493, 812-827.

Wang, M., Duan, L., Wang, J., Peng, J., Zheng, B., 2020. Determining the width of lake riparian buffer zones for improving water quality base on adjustment of land use structure. Ecol. Eng. 158, 106001

Wang, Y., Yang, J., Liang, J., Qiang, Y., Fang, S., Gao, M., Fan, X., Yang, G., Zhang, B., Feng, Y., 2018. Analysis of the environmental behavior of farmers for non-point source pollution control and management in a water source protection area in China. Sci. Total Environ. 633, 1126-1135

Wang, Y., Liang, J., Yang, J., Ma, X., Li, X., Wu, J., Yang, G., Ren, G., Feng, Y., 2019. Analysis of the environmental behavior of farmers for non-point source pollution control and management: an integration of the theory of planned behavior and the protection motivation theory. J. Environ. Manag. 237, 15-23.

Westerink, J., Opdam, P., Van Rooij, S., Steingröver, E., 2017. Landscape services as boundary concept in landscape governance: building social capital in collaboration and adapting the landscape. Land Use Policy 60, 408-418.

Yu, S., Lu, H., 2018. An integrated model of water resources optimization allocation based on projection pursuit model-Grey wolf optimization method in a transboundary river basin. J. Hydrol. 559, 156-165.

Zanella, M.A., Schleyer, C., Speelman, S., 2014. Why do farmers join Payments for Ecosystem Services (PES) schemes? An assessment of PES water scheme participation in Brazil. Ecol. Econ. 105, 166-176. 